$\Phi=\Phi$

\title{
Management of recurrent peripheral giant cell granuloma -a case report
}

\author{
Santha Kumari Prathypaty ${ }^{1 *}$, Santhi Priya Potharaju ${ }^{2}$, Ravi Kanth Chintala ${ }^{3}$, \\ Satheesh Kumar Guvvala ${ }^{4}$, Jai Krishna Srikanth Kolliboyana ${ }^{5}$ \\ ${ }^{1}$ Government Dental College \& Hospital \\ ${ }^{2}$ Government Dental College \& Hospital \\ ${ }^{3}$ Army Dental Corps \\ ${ }^{4}$ Government Dental College \& Hospital \\ ${ }^{5}$ Central Michigan University. \\ *Corresponding author E-mail:drpriyatweety@gmail.com
}

\begin{abstract}
Peripheral giant cell granuloma (PGCG) which is also called as Giant cell Epulis is one of the most common reactive hyperplastic lesions of the oral cavity. There are various etiologies relating PGCG which include local irritation, trauma, tooth extraction, irregular restorations, plaque, calculus, chronic infection \& impacted food. One important other etiology of this benign tumor is its origin from periosteum or periodontal membrane. Excision of the lesion completely along with extraction of involved tooth is the option of treatment to prevent recurrence of the lesion in some cases. This case report describes the recurrence of the Peripheral giant cell granuloma even after complete excision in 3 months.Management of recurrent Peripheral giant cell granuloma by surgical excision of the lesion was carried out along with extraction of the associated tooth and curettage of the bone walls. Profuse bleeding after tooth extraction was managed by gel-spun. Periodic recalls doesn't show any recurrence until one month.
\end{abstract}

Keywords: Benign Tumor; Excision; Giant Cell Epulis; Osteoclastoma; Peripheral Giant Cell.

\section{Introduction}

Peripheral Giant Cell Granuloma (PGCG) is a relatively common tumor like growth of the oral cavity (Neville BW et al. 2009) accounting 7\% of all benign tumors of the jaw (PourMAH et al. 2003). It is also known as peripheral giant cell reparative granuloma (Neville BW et al. 2009), giant cell epulis, osteoclastoma, giant cell hyperplasia (PourMAH et al. 2003). Jaffe first named it as giant cell reparative granuloma (Jaffe HL 1953). Bernier and Cahn suggested the term peripheral giant cell reparative granuloma (Rajendran R \& Sivapathsundaram B 2006). Though it is not a true neoplasm it is a benign hyperplastic reactive lesion (Chapparo A et al. 2005) occurred in response to local irritation such as trauma, tooth extraction, irregular restorations, plaque, calculus, chronic infection, food impaction and chronic trauma (Motamedi $\mathrm{MH}$ et al. 2007). Some believe that it has originated from osteoclasts, while some suggest them to arise from mononuclear phagocyte system. Some authors also suggested that it originates from periosteum or the periodontal ligament. It is more frequent in women than in men with a slightly higher prevalence in the 30-70 year-old-age group and largely affects the lower jaw (55\%) than the upper jaw (Reichart PA \& Philipsen H 2004). Clinically swelling appears as soft or firm with red to bluish color on surface. Swelling may be sessile or pedunculated with anterior to molar prevalence. Localized bone involvement can be identified in the radiographs. Recurrence of the lesion even after excision is reported in $10 \%$ of cases. Hence thorough surgical excision of the lesion and curettage that exposes all bony walls is recommended. Multiple recurrences with loss of adjacent teeth are a potential compli- cation. This case report describes the procedure of surgical excision of a recurrent PGCG with extraction of associated tooth and management of profuse bleeding from the extracted socket wall during the treatment procedure.

The purpose of this case report is to illustrate an instance of recurrent PGCG and its management to prevent the recurrence based on the age of patient history and clinical features.

\section{Case report}

A 45-year-old female patient was referred by a private practitioner for evaluation and treatment of a recurrent gingival swelling located at the buccal side of the lower right first and second premolar region (\#44, \#45 Fig 1). History revealed that excision of the localized swelling in the same area had been performed previously by the patient's dentist. Microscopic examination was not carried out. Within in three months recurrence of the swelling started as a small one and progressively increased to the present size over a period of one year. Patient's medical history was uneventful. On intraoral examination a single, oval shaped, pedunculated lesion, with reddish purple color was observed adjacent to missing \#46. The involved tooth 45 also presents Grade I mobility. The swelling was firm in consistency. The surface over swelling was smooth \& shiny and measured $1.5 \mathrm{~cm}$ in length \& 0.5 to $1 \mathrm{~cm}$ in width. Intra oral peri-apical radiograph shows bone loss and periodontal ligament space widening with respect to 45 . Edentulous area in relation to \#46 shows horizontal bone loss (Fig 2). 


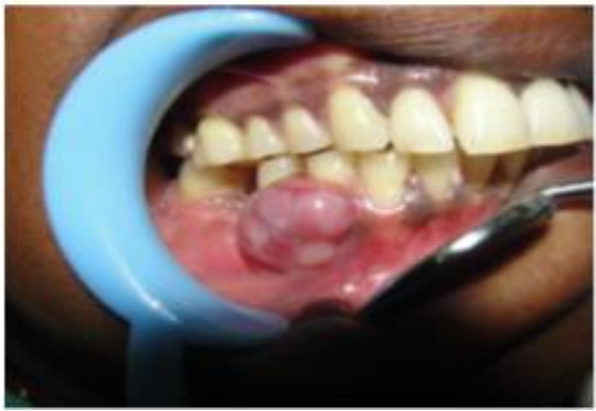

Fig. 1: Pre-Operative.

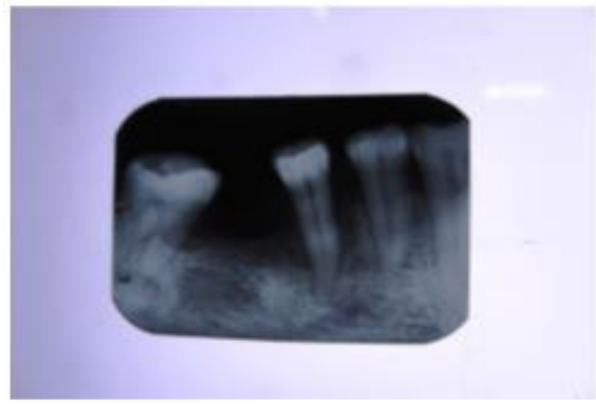

Fig. 2: Iopa-Boneloss.

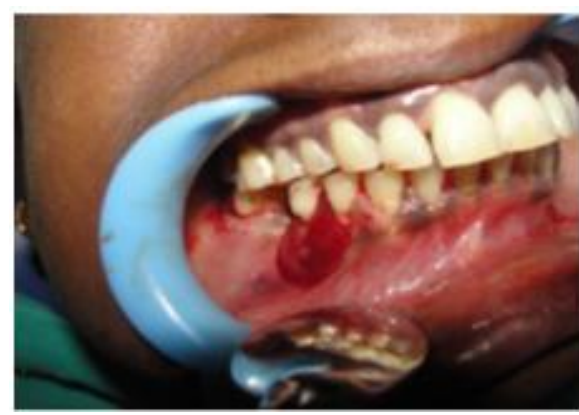

Fig. 3: After Excision.

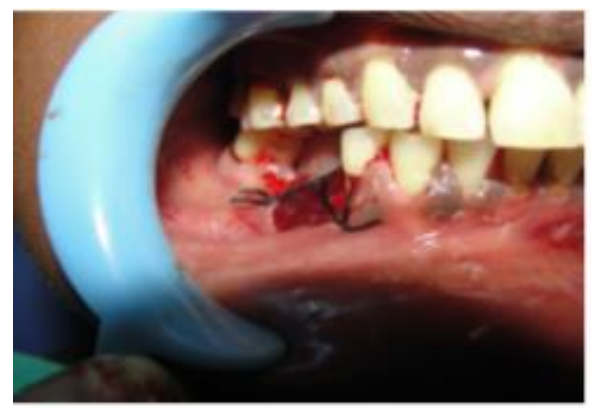

Fig. 4: After Tooth Extraction and Suturing.

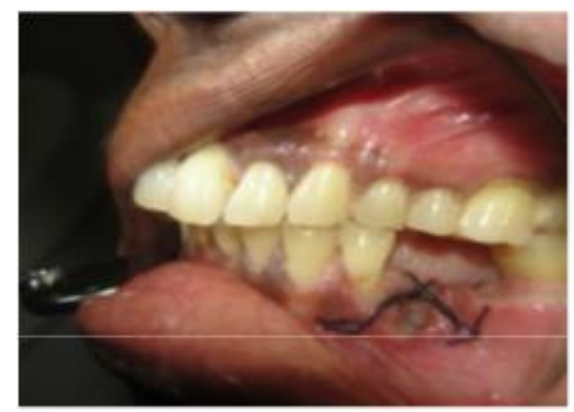

Fig. 5: Gel-Spun Placed.

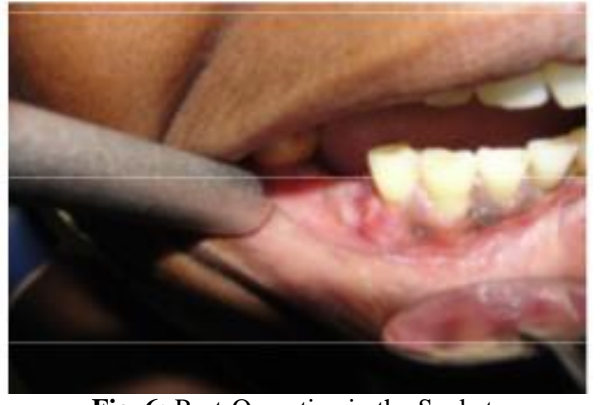

Fig. 6: Post-Operative in the Socket.

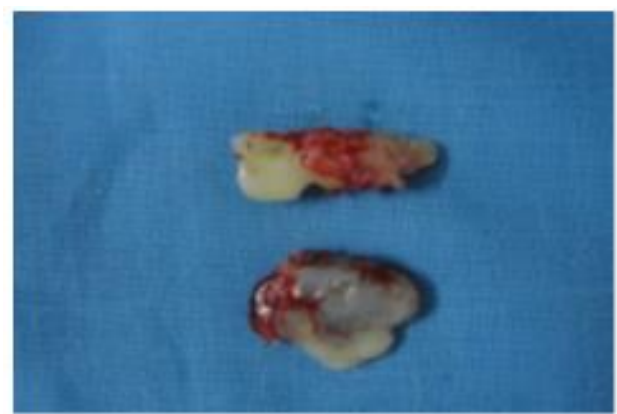

Fig. 7: Excised Tissue and Extracted Tooth.

\section{Treatment}

Thorough scaling and root planing was done. After phase I therapy, excision of the swelling was done under local anesthesia by using BP blade No; 15 . Any remnants of the swelling were thoroughly removed (Fig .3). The related tooth i.e. 45 was extracted and thorough bone curettage was also done. After extraction of the tooth there was profuse bleeding from the wall of socket (Fig.4). The bleeding was uncontrollable and pulsating. Bone wax was applied to the socket wall to control the bleeding. Gel spun was placed in the socket and suturing was given (Fig.5). Patient was recalled after 1 week for suture removal and instructions were given about oral hygiene maintenance (Fig. 6). Healing was uneventful

\section{Histological features}

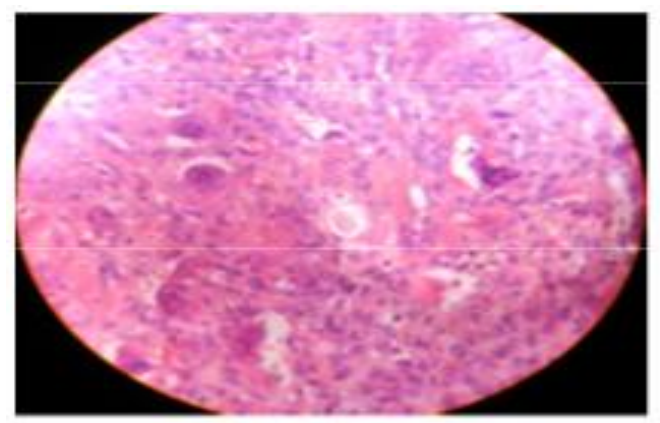

Fig. 8: Histopathological Slide.

The excised lesion was sent for microscopic examination (Fig.8). Histologically it shows abundant multinucleated giant cells, inflammatory cells, hemosiderin deposits, mature bone or osteoid in highly cellular background of spindle shaped mesenchymal cells and inflammatory hemorrhage. The main feature that differentiates PGCG from other reactive lesions is the abundance of multinucleated giant cells.

\section{Discussion}

The present report describes a swelling localized to gingiva, which was diagnosed as PGCG in a middle aged 45 year old female pa- 
tient, recurring after a gap of 1 year with respect to mandibular right second premolar. PGCG has its highest incidence in the fourth decade of life (N Shadman et al. 2009) and in females more than males with a proportion of 1:1.5 (Katsikeris $\mathrm{N}$ et al.1998). PGCG is more common in the mandible rather than maxilla with a proportion 2.4:1 and mostly occursanterior to molar regions i.e., premolar zones (Giansanti JS \& Waldron CA 1969).

In the present case the lesion was associated with premolar area on lower mandible of middle aged female and correlates with the common features of PGCG. From a clinical prospective, it is difficult to distinguish between PGCG and Pyogenic Granuloma. It can be differentiated from other reactive lesions histologically mainly by the abundance of multinucleated giant cells. Some investigators believe that multinucleated giant cells are derived from osteoclasts, and others believe that they originate from mononuclear phagocyte system (Neville BW et al. 2009). The mechanism that activates or recruits osteoclasts in PGCG are still unknown (Katsikeris $\mathrm{N}$ et al.1998). Some authors also suggested that it originates from periosteum or the periodontal ligament (Regezi JA et al. 2009). Cupping resorption of underlying alveolar bone is sometimes seen radiographically, although it develops in soft tissue which is seen when the lesion occurs on edentulous ridge ((Regezi JA et al. 2009).

In an another recent study by Liu B et al. (2003), expression of mRNA by the receptor activator of nuclear factor kappa $\beta$ ligand (RANKL) is shown to be essential in the osteoclastogenesis, its receptor, receptor activator of NF-kappa $\beta$ (RANK) and its decoy receptor, osteoprotegerin (OPG). They said that RANKL, OPG and RANK expressed in these lesions may play an important role in the formation of multinucleated giant cells.

In this case, PGCG was present adjacent to the recently extracted edentulous space. Radiograph also shows bone loss in the edentulous area and in the involving tooth \#45.

Most lesions respond satisfactorily to thorough surgical excision, with exposure of all the bony walls. When the periodontal membrane is affected, extraction of the adjacent tooth may prove necessary to insure full resection though this is initially contraindicated (N Shadman et al. 2009).

Recurrences are believed to be related to lack of inclusion of the periosteum or periodontal ligament in the excised specimen. Hence, in this case re-excision was performed with extraction of associated tooth believing that PGCG has its origin from the adjacent periodontal ligament (Bhaskar SN et al. 1971).There was also profuse bleeding after the extraction of the tooth \#45, in which measures were taken to control the bleeding. The respective area also showed bone loss proving the bony involvement by PGCG.Aggressivetendenciesormalignanttransformationoftheselesi onshasneverbeen reported (Regezi JA et al. 2009). One year follow-up of the present case showed no recurrence indicating that the given treatment along with tooth extraction was sufficient to treat PGCG.

\section{Conclusion}

Surgical excision of the swelling performed. Recurrence of PGCG was considered while performing excision. One of the etiologies is PGCG originates from the periodontal ligament space. As first excision lead to recurrence of the lesion, extraction of the associated tooth with excision of the lesion was performed under local anesthesia. Regular check-up of one year follow-up showed no recurrence.

\section{References}

[1] Neville BW, Damm DD, Allen CM, Bouquot JE. (2009) Soft Tissue Tumors. Oral and Maxillofacial Pathology ( $3^{\text {rd }}$ ed), Saunders, St Louis, p. 507-563.

[2] Pour MAH, Rad M, Mojtahedi A. (2003). A survey of soft tissue tumor-like lesions of oral cavity: A clinicopathological study. Iranian Journal of Pathology 3, 81-87.
[3] Jaffe HL. (1953) Giant cell reparative granuloma, traumatic bone cyst and fibrous (fibro-osseous) dysplasia of jaw bones. Oral Surgery Oral Medicine Oral Pathology 6:15975.http://dx.doi.org/10.1016/0030-4220(53)90151-0.

[4] Rajendran R, Sivapathsundaram B. (2006) Benign and Malignant Tumors of the oral cavity.Shafer's Text book of Oral Pathology $\left(5^{\text {th }}\right.$ Ed) Elsevier, New Delhi, p.113-308

[5] Chapparo-Avendano A, Berini-AytesL,Gay-Escoda C. (2005)Peripheral giant cell. A report of five cases and review of the literature. Medicina Oral Patologia Oral Y CirugiaBucal10:53-57

[6] Motamedi MH,Eshghyar N, Jafari SM, Lassemi E ,Navi F, Abbas FM, Khalifesh S, Eshkevari PS(2007)Peripheral central giant cell granulomas of the jaws: a demographic study. Oral Surgery Oral Medicine Oral Pathology Oral Radiology Endodontics103:e39e43DOI: http://dx.doi.org/10.1016/j.tripleo.2006.12.022.

[7] Reichart PA Philipsen H. (2004) Atlas de Patolgia Oral. Masson, Barcelona, p.164

[8] N Shadman, S FarzinEbrahimi, S Jafar. (2009). Peripheral Giant cell Granuloma. A Review of 123 cases Dental Research Journal, 6(1): 47-50.

[9] Katsikeris N, Kakarantza-Angelopoulou E, Angelopoulos AP (1988) Peripheral giant cell granuloma.Clinicopathologic study of 224 new cases and review of 956 reported cases. International Journal of Oral and Maxillofacial Surgery, 7(2):949.http://dx.doi.org/10.1016/S0901-5027(88)80158-9.

[10] Giansanti JS, Waldron CA (1969) Peripheral giant cell granuloma. Review of 720 cases. Journal of Oral Surgery, 27:787-91.

[11] Regezi JA, Sciubba JJ, Jordan RC. (2009) Red Blue lesions. Oral Pathology. Clinical Pathologic Correlations (5th ed), Saunders; St Louis p.107-25.

[12] Liu B, Yu SF, Li TJ (2003) Multinucleated giant cells in various forms of giant cell containing lesions of the jaws express features of osteoclasts. Journal of oral pathology and medicine, 32: 36775.http://dx.doi.org/10.1034/j.1600-0714.2003.00126.x.

[13] Bhaskar SN, Cutright DE, Beasley JD, Perez B. (1971) Giant cell reparative granuloma (peripheral): Report of 50 cases. Journal of Oral Surgery, 29: 110-15. 